ISSN 1899-3192

e-ISSN 2392-0041

\title{
Maria Nieplowicz
}

Uniwersytet Ekonomiczny we Wrocławiu

e-mail: maria.nieplowicz@ue.wroc.pl

EWOLUCJA ZRÓWNOWAŻONEJ KARTY WYNIKÓW

NA POTRZEBY ZARZĄDZANIA BANKIEM

THE EVOLUTION OF BALANCED SCORECARD

IN RESPECT OF BANK MANAGEMENT NEEDS

DOI: 10.15611/pn.2018.506.07

JEL Classification: G21, M40, M49

Streszczenie: Obecnie banki, które chcą przetrwać i rozwijać się, muszą poradzić sobie z dynamicznymi zmianami, rosnącymi wymaganiami klientów i ostrą konkurencją. Wymagania rynku powodują, że banki muszą posiadać bardzo dobrą strategię oraz właściwy instrument, który umożliwi im odpowiednio dokumentować, komunikować i mierzyć strategię banku oraz postępy w jej realizacji. Doświadczenia światowe wskazuję, że instrumentem tym może być zrównoważona karta wyników. Biorąc pod uwagę specyfikę sektora bankowego, zasadne jest przyjęcie dodatkowej perspektywy, odpowiedniej do wspierania planowania, zarządzania i kontroli ryzyka. Należy także przedstawić kluczowe determinanty charakteryzujące sprawne zarządzanie w warunkach ryzyka. W związku z tym głównym celem artykułu jest przedstawienie ewolucji zrównoważonej karty wyników dla banku. W artykule zastosowano następujące metody badawcze: badania literatury, wnioskowane przez analogię, analizę regulacji prawnych (ustawa prawo bankowe) oraz analizę przypadku.

Słowa kluczowe: zrównoważona karta wyników, bank, perspektywa ryzyka.

Summary: Nowadays, banks that want to surrive have to cope with dynamic changes, growing customer requirements and fierce competition. The requirements of the global economy mean that banks must have a very good strategy, as well as the right instrument, which will enable them to properly document, communicate and measure the bank's strategy and progress in its implementation. World experience shows that this instrument could be a Balanced Scorecard. Taking into account the specifics of the banking sector, it is justified to introduce an additional perspective that is suitable for supporting risk planning, management and control. In the risk perspective, key determinants characterizing efficient risk management should be presented. Therefore, the main goal of the article is to present the evolution of a Balanced Scorecard for the bank. In this article, the following research methods were used: literature research, reasoning by analogy, analysis of the general regulations (Banking Law Act), and case analysis.

Keywords: Balanced Scorecard, bank, risk perspective. 


\section{Wstęp}

W dzisiejszych czasach banki, które chcą się utrzymać, muszą poradzić sobie z dynamicznymi zmianami, rosnącymi wymaganiami klientów i ostrą konkurencją. Wymagania rynku powodują, że banki muszą posiadać bardzo dobrą strategię, a także właściwy instrument, który umożliwi im odpowiednio dokumentować, komunikować i mierzyć strategię banku oraz postępy w jej realizacji. Doświadczenia światowe wskazują, że instrumentem tym może być zrównoważona karta wyników, składająca się z czterech perspektyw: finansowej, klienta, procesów wewnętrznych i rozwoju. Jednak liczba i zawartość czterech klasycznych perspektyw nie powinna być traktowana jako niemodyfikowalna koncepcja. Twórcy zrównoważonej karty wyników stworzyli pewien model, który w razie potrzeby może zostać dostosowany do potrzeb organizacji go wdrażającej. Perspektywa stanowi przecież ważny obszar działalności danej organizacji i jeżeli jest potrzeba wyodrębnienia kolejnej perspektywy, to jest to jak najbardziej wskazane. Poszczególne perspektywy muszą ostatecznie odzwierciedlać krytyczne dla korporacji czynniki sukcesu. Biorąc pod uwagę specyfikę sektora bankowego, zasadne jest wprowadzenie dodatkowej perspektywy, która jest odpowiednia do wspierania planowania, zarządzania i kontroli ryzyka. W perspektywie ryzyka należy przedstawić kluczowe determinanty charakteryzujące sprawne zarządzanie w warunkach ryzyka.

W związku z tym głównym celem artykułu jest przedstawienie ewolucji zrównoważonej karty wyników dla banku. W artykule zastosowano następujące metody badawcze: badania literatury, wnioskowane przez analogię, analizę regulacji prawnych (ustawa prawo bankowe) oraz analizę przypadku.

\section{Rola zrównoważonej karty wyników w zarządzaniu korporację}

Doświadczenia w stosowaniu zrównoważonej karty wyników w zarządzaniu korporacją sięgają już ponad ćwierć wieku. Pierwsze działania zostały podjęte w 1990 roku, kiedy to Instytut Nolan Norton - placówka badawcza firmy KPMG - rozpoczął projekt badawczy nazwany „Mierzenie efektywności w organizacjach przyszłości" [Kaplan, Norton 2011, s. 17]. Przeprowadzony był on pod kierownictwem D.P. Nortona, a R.S. Kaplan sprawował funkcję konsultanta naukowego. Przez rok trwały spotkania $\mathrm{z}$ reprezentantami 12 przedsiębiorstw ${ }^{1} \mathrm{~W}$ celu stworzenia nowego modelu mierzenia dokonań korporacji, gdyż ten oparty na wskaźnikach finansowych był już nieco przestarzały.

Efektem tych spotkań było opracowanie zrównoważonej karty wyników. W jej skład wchodziły cztery perspektywy (finansowa, klienta, procesów wewnętrznych

1 Były to: Advanced Micro Devices, American Standard, Apple Computer, Bell South, CIGNA, Conner Peripherals, Cray Research, DuPont, Electronic Data Systems General Electric, Hewlett Packard i Shell Canada. Są to przedstawiciele przedsiębiorstw produkcyjno-usługowych, przemysłu ciężkiego i branży nowoczesnych technologii. 
oraz rozwoju), cele strategiczne, mierniki osiągania celów (mierniki przeszłości), czynniki przyszłego sukcesu (mierniki przyszłości) oraz działania. Następnie kilka organizacji uczestniczyło w eksperymencie polegającym na wdrożeniu prototypu zrównoważonej karty wyników (m.in. bank) [Kaplan, Norton 1992, s. 71-79]. Potwierdziły one realną możliwość zastosowania zrównoważonej karty wyników w praktyce.

Potem menedżerowie zaczęli stosować zrównoważoną kartę wyników w zasadniczych elementach procesu zarządzania, a mianowicie do: indywidualnego i grupowego ustalaniu celów, motywowania i wynagradzania, alokacji zasobów, planowania i budżetowania, monitorowania strategii oraz uczenia się organizacji [Kaplan, Norton 1996, s. 75-85; 2011, s. 19]. Doświadczenia z funkcjonowania zrównoważonej karty wyników w korporacjach spowodowało wprowadzenie czterech nowych procesów, które przyczyniają się do powiązania celów strategicznych z działaniami krótkoterminowymi, a należą do nich [Kaplan, Norton 2011, s. 29-38]:

- dopracowanie wizji i strategii oraz zdobycie poparcia dla realizacji wizji i strategii,

- wyjaśnienie celów i mierników strategicznych oraz ich integracja z systemami zarządzania i premiowania,

- planowanie, wyznaczanie celów i podejmowanie inicjatyw strategicznych oraz alokacja zasobów i wyznaczanie terminów realizacji,

- usprawnianie systemów monitorowania realizacji strategii i uczenia się organizacji.

Budowanie zrównoważonej karty wyników rozpoczyna się od przełożenia strategii na konkretne cele w każdej z perspektyw. Na początku definiowane są cele finansowe, ponieważ to one są wyznacznikiem dla sformułowania celów i mierników dla pozostałych perspektyw zrównoważonej karty wyników. Jednocześnie też wyniki finansowe są ostateczną miarą skuteczności strategii, wskazując właścicielom korporacji na efektywność zainwestowanych środków.

Po określeniu strategii finansowej korporacji następuje wybór klientów i segmentów rynków, na których zamierza ona konkurować, oraz definiuje się mierniki z nimi związane. W perspektywie procesów wewnętrznych następuję identyfikacja działań i procesów zasadniczych dla osiągnięcia celów przyjętych w perspektywach klienta i finansowej. Następnie w perspektywie rozwoju określane są zasoby konieczne do wprowadzenia zmian i osiągnięcia celów ujętych w perspektywie finansowej, klienta i procesów wewnętrznych.

Cele strategiczne i mierniki zdefiniowane w zrównoważonej karcie wyników komunikowane są całej korporacji (np. poprzez biuletyny zakładowe, tablice ogłoszeń, intranet). Dzięki temu następuje wyjaśnienie pracownikom celów, jakie należy osiągnąć, aby przyjęta strategia została pomyślnie wdrożona. Pracownicy powinni sobie uświadomić cele i mierniki na poziomie całej korporacji, aby móc ustalić własne cele, przyczyniając się w ten sposób do realizacji ogólnej strategii. Dodatkowo powiązanie celów strategicznych zawartych w zrównoważonej karcie wyników 
z celami osobistymi oraz wprowadzenie systemu płac i premii powiązanego ze zrównoważoną kartą wyników spowodują, że pracownicy zrozumieją związek między wynikami korporacji a własnym wynagrodzeniem.

W procesie zarządzania należy określić konkretne zadania przy użyciu zrównoważonego zbioru mierników przeszłości i przyszłości. Poprzez porównania obecnego poziomu miernika z jego poziomem docelowym zostaje wyznaczona luka, którą trzeba wyeliminować, podejmując określone inicjatywy strategiczne. W związku z tym zrównoważona karta wyników nie tylko służy do mierzenia zmian, lecz także je wymusza.

Zrównoważona karta wyników dzięki swojej konstrukcji umożliwia połączenie planowania strategicznego z procesem tworzenia budżetu. W każdej perspektywie dla każdego celu długookresowego są ustalane cele cząstkowe na najbliższy rok (tzw. kamienie milowe). Umożliwiają one ocenę krótkoterminowych postępów podczas osiągania celów strategicznych.

Zrównoważona karta wyników dzięki systemowi mierników z ich wielkościami docelowymi jest instrumentem bardzo pomocnym w procesach monitorowania i kontroli, które wspomagają procesy podejmowania decyzji. Uwzględnienie zrównoważonej karty wyników w procesie strategicznego uczenia się uważane jest przez Kaplana i Nortona za najbardziej twórczy i najważniejszy aspekt całej koncepcji zarządzania za pomocą zrównoważonej karty wyników [Kaplan, Norton 2011 s. 33]. Dzięki temu kadra zarządzają skupia się na monitorowaniu wdrażania strategii, podejmowaniu działań korygujących czy też dokonuje fundamentalnych zmian samej strategii. Proces strategicznego uczenia się zamyka pętlę sprzężenia zwrotnego i jednocześnie uruchamia kolejne cztery omawiane wcześniej procesy, tj. dopracowania wizji i strategii, wyjaśniania i integracji, planowania i wyznaczania celów oraz monitorowania realizacji strategii i uczenia się.

\section{Wykorzystanie zrównoważonej karty wyników w zarządzaniu bankiem}

Wdrożenie zrównoważonej karty wyników w bankach może być bardzo trudne, ponieważ istnieje ogromna pokusa, aby skupić się wyłącznie na miernikach finansowych. Jak wiadomo, banki i inne instytucje finansowe zarządzają pieniędzmi własnymi i obcymi, aby zarobić jeszcze więcej pieniędzy. Może pojawić się tendencja ignorowania mierników niefinansowych, które jednak mają bezpośredni wpływ na wyniki finansowe tych korporacji. Problem polega na tym, że mierniki finansowe pokazują, co już się stało z bankiem, podczas gdy bardzo ważne jest, aby planować z wyprzedzeniem i wiedzieć, co stanie się w przyszłości. Tu mogą pomóc mierniki niefinansowe. Dlatego też zrównoważona karta wyników okazała się najbardziej skutecznym narzędziem do pomiaru i zarządzania dokonaniami banku. 
W literaturze przedmiotu można znaleźć przypadki zrównoważonej karty wyników dla banku, np. Consumer Bank, Bank of Tokio-Mitsubishi HQA [Kaplan, Norton 2004, s. 21 i 208], National Bank [Kaplan, Norton 2001, s. 117-125]. W prezentowanych przypadkach stosowano cztery standardowe perspektywy zrównoważonej karty wyników, tj. finansową, klienta, procesów wewnętrznych i rozwoju, choć czasami ta ostatnia była nazywana perspektywą kapitału ludzkiego. Ta zmiana nazwy jest zrozumiała, ponieważ w perspektywie rozwoju ujmuje się trzy rodzaje kapitału, tj. ludzki, informacyjny i organizacyjny, więc zmiana nazwy perspektywy miała za zadanie podkreślenie znaczenia kapitału ludzkiego. Przykładowa zrównoważona karta wyników dla banku została przedstawiona w tab. 1.

Tabela 1. Zrównoważona karta wyników Metro Banku

\begin{tabular}{|c|c|c|}
\hline \multirow{2}{*}{ CELE STRATEGICZNE } & \multicolumn{2}{|c|}{ MIERNIKI STRATEGICZNE } \\
\hline & MIERNIKI PRZESZŁOŚCI & MIERNIKI PRZYSZŁOŚCI \\
\hline \multicolumn{3}{|c|}{ PERSPEKTYWA FINANSOWA } \\
\hline Zwiększyć zwrot z kapitału & Stopa zwrotu z inwestycji & \\
\hline $\begin{array}{l}\text { Zróżnicować strukturę } \\
\text { przychodów }\end{array}$ & Wzrost przychodów & Struktura przychodów \\
\hline Zredukować koszty & $\begin{array}{l}\text { Redukcja kosztów } \\
\text { obsługi depozytów }\end{array}$ & \\
\hline \multicolumn{3}{|c|}{ PERSPEKTYWA KLIENTA } \\
\hline $\begin{array}{l}\text { Zwiększyć stopień zadowolenia } \\
\text { klientów z naszych produktów } \\
\text { i pracowników }\end{array}$ & Udział w segmencie rynku & $\begin{array}{c}\text { Intensywność relacji } \\
\text { z klientem }\end{array}$ \\
\hline $\begin{array}{l}\text { Zwiększyć stopien zadowolenia } \\
\text { „po sprzedaży” }\end{array}$ & Lojalność klientów & Badania stopnia zadowolenia \\
\hline \multicolumn{3}{|c|}{ PERSPEKTYWA PROCESÓW WEWNĘTRZNYCH } \\
\hline \multicolumn{3}{|c|}{ Zrozumieć potrzeby klientów } \\
\hline $\begin{array}{l}\text { Rozwijać innowacyjne } \\
\text { produkty }\end{array}$ & Przychody z nowych produktów & Cykl rozwoju produktów \\
\hline Rozwijać sprzedaż wzajemną & Wskaźnik sprzedaży wzajemnej & $\begin{array}{l}\text { Liczba godzin } \\
\text { spedzonych z klientem }\end{array}$ \\
\hline $\begin{array}{c}\text { Przesunąc klientów do mniej } \\
\text { kosztownych kanałów } \\
\text { dystrybucji }\end{array}$ & Zmiana struktury dystrybucji & \\
\hline $\begin{array}{c}\text { Zminimalizować błędy } \\
\text { operacyjne }\end{array}$ & Wskaźnik błędów obsługi & \\
\hline Zwiększyć szybkość obsługi & Czas realizacji wniosku & \\
\hline \multicolumn{3}{|c|}{ PERSPEKTYWA ROZWOJU } \\
\hline $\begin{array}{l}\text { Rozwijać strategiczne } \\
\text { umiejętności }\end{array}$ & & $\begin{array}{l}\text { Wskaźnik obsady strategicz- } \\
\text { nych stanowisk }\end{array}$ \\
\hline $\begin{array}{l}\text { Zapewnic dostęp do informacji } \\
\text { strategicznych }\end{array}$ & & $\begin{array}{l}\text { Wskaźnik dostępu } \\
\text { do informacji strategicznych }\end{array}$ \\
\hline $\begin{array}{c}\text { Uzgodnić cele osobiste z celami } \\
\text { organizacji }\end{array}$ & $\begin{array}{l}\text { Zadowolenie pracowników } \\
\text { Przychody na pracownika }\end{array}$ & $\begin{array}{l}\text { Zbieżność celów osobistych } \\
\text { z celami organizacji }(\%)\end{array}$ \\
\hline
\end{tabular}

Źródło: [Kaplan, Norton 2011, s. 146]. 
Przedstawiony w tab. 1 przykład zrównoważonej karty wyników dla Metro Banku został omówiony w pracy [Nieplowicz 2003, s. 214-221]. Jednakże analizując cele strategiczne zawarte $\mathrm{w}$ tab. 1, nie znajduje się celów odnośnie do zarządzania w warunkach ryzyka. W innym przypadku zrównoważonej karty wyników dla banku cele odnośnie do zarządzania w warunkach ryzyka znajdują się w perspektywie procesów wewnętrznych. W perspektywie tej zawarte cele strategiczne są pogrupowane w trzy tematy strategiczne: wzrost przychodów, zarzadzanie w warunkach ryzyka i zwiększenie rentowności [Kaplan, Norton 2004, s. 38]. Cele dotyczące ryzyka to proaktywne zarządzanie w warunkach ryzyka i doskonalenie planu awaryjnego/planu ciągłości działania.

Koncepcja zrównoważonej karty wyników sugeruje, że warunkiem osiągnięcia celów przez bank jest zrównoważenie w czterech podstawowych perspektywach: finansowej, klienta, procesów wewnętrznych oraz rozwoju. $Z$ biegiem czasu różne korporacje na świecie wdrażające zrównoważoną kartę wyników zaczęły stosować dodatkowe perspektywy, takie jak: konkurencyjna, kooperacyjna, koncernu, organizacyjna, komunikacyjna, wdrożeniowa, Internetu, dostawców, innowacji, urzędów i publiczna [Friedag, Schmidt 2003, s. 178-185]. Selekcja perspektyw przy opracowywaniu zrównoważonej karty wyników jest indywidualna i uwarunkowana charakterem działalności danej jednostki i przekształceń aktualnie w niej zachodzących. Nie jest zalecane stosowanie jednocześnie wszystkich wskazanych perspektyw, ponieważ zrównoważona karta wyników utraciłaby swoją przejrzystość, co stanowi jedną z jej głównych zalet.

\section{Perspektywa ryzyka jako rozszerzenie zrównoważonej karty wyników na potrzeby zarządzania bankiem}

Ryzyko jest na stałe wkomponowane w działalność prowadzoną przez każdy bank, gdyż pełnią one funkcje pośredników finansowych w gospodarce każdego państwa. W działalności banku ryzyko rozumie się jako zdarzenie lub szereg zdarzeń oddziałujących negatywnie na sytuację banku. Wyznacznikiem ryzyka jest możliwość wystąpienia straty lub zysku różnego od wielkości zakładanej. Ryzyko dotyczy także sytuacji, gdy posiadane informacje są niewystarczające, jednak pozwalają na oszacowanie prawdopodobieństwa powstania określonych zjawisk związanych z podjęciem decyzji.

Na rozmiary ryzyka występującego w działalności bankowej ma wpływ wiele czynników, z których znaczna część ma charakter zewnętrzny, niezależny od działań banku. Należą do nich m.in. (por. [Czerwińska, Jajuga (red.) 2016, s. 30]):

- czynniki ogólnogospodarcze: polityka gospodarcza państwa, polityka Rady Polityki Pieniężnej, stopa inflacji, wysokość deficytu budżetowego;

- czynniki społeczne: zachowanie klientów banku, skłonność do oszczędzania bądź konsumpcji; czynniki polityczne: ataki terrorystyczne, prowadzone wojny; 
- czynniki demograficzne: struktura ludności, stopa bezrobocia; czynniki techniczne: postęp w zakresie informatyki i telekomunikacji;

- czynniki o charakterze międzynarodowym, takie jak: liberalizacja w funkcjonowaniu rynków finansowych, integracja ekonomiczna gospodarek, postęp techniczny, globalizacja rynków finansowych.

Zarządzanie ryzykiem bankowym obejmuje szereg działań mających na celu świadomą, planową i celową analizę i sterowanie ryzykiem występującym w działalności bankowej [Iwanowicz-Drozdowska i in. 2010, s. 235-237]. Dodatkowym jego elementem jest systematyczna kontrola podejmowanych działań. Proces ten powinien mieć charakter planowy i celowy, tj. nie może mieć on znamion o charakterze działania sporadycznego i krótkofalowego, lecz powinien mu towarzyszyć dalszy horyzont czasowy oraz systematyczność działania.

Każdy bank ma obowiązek wdrożenia procedur zarządzania w warunkach ryzyka adekwatnych do skali prowadzonej działalności ${ }^{2}$. W procesie zarządzania ryzykiem bankowym ważnym etapem jest pomiar ryzyka, gdyż zarządzać ryzykiem można tylko wtedy, gdy jest ono mierzalne. Decydujące znaczenie dla zarządzania w warunkach ryzyka ma ocena ryzyka łącznego, rozumianego jako wielkość poszczególnych pojedynczych zagrożeń, prawdopodobieństwo ich wystąpienia oraz wzajemnej korelacji między nimi [Jajuga (red.) 2015, s. 178]. W ramach sterowania ryzykiem mogą być podejmowane kroki oddziałujące na przyczyny występowania ryzyka, które mają na celu ograniczenie wielkości ryzyka; ten rodzaj działań określany jest jako aktywna strategia przeciwdziałania ryzyku. W ramach tej strategii można podejmować różne przedsięwzięcia: unikanie ryzyka poprzez nieangażowanie się $\mathrm{w}$ transakcje, w stosunku do których ryzyko wydaje się szczególnie duże (np. wprowadzanie limitów zaangażowania kredytowego w poszczególne branże), zmniejszanie wielkości ryzyka poprzez zaostrzone kryteria oceny zdolności kredytowej oraz systematyczny bieżący monitoring spłaty kredytu i zabezpieczeń, przenoszenie ryzyka na inne podmioty (np. ubezpieczanie kredytów), dywersyfikację ryzyka, w której wyniku ryzyko ponoszone w określonych obszarach działalności zostanie zrównoważone szansami w innych obszarach.

Podsumowując, ze względu na ogromne znaczenie ryzyka w działalności ban$\mathrm{ku}, \mathrm{w}$ praktyce wdrożeń zrównoważonej karty wyników dla banku pojawiła się dodatkowa perspektywa obejmująca ten ważny obszar działalności banku, a mianowicie perspektywa ryzyka. W perspektywie ryzyka należy przedstawić kluczowe determinanty charakteryzujące sprawne zarządzanie $\mathrm{w}$ warunkach ryzyka. $\mathrm{W}$ tabeli 2 przedstawiono przykłady celów, mierników i działań w perspektywie ryzyka zrównoważonej karty wyników dla banku.

2 Szerzej w Ustawie z dnia 29 sierpnia 1997 r. - Prawo bankowe. 
Tabela 2. Cele, mierniki i działania w perspektywie ryzyka zrównoważonej karty wyników dla banku

\begin{tabular}{|l|l|l|}
\hline \multicolumn{1}{|c|}{ Cele strategiczne } & \multicolumn{1}{|c|}{ Mierniki } & \multicolumn{1}{c|}{ Działania } \\
\hline $\begin{array}{l}\text { Ścisłe przestrzeganie przepisów } \\
\text { i instrukcji dotyczących polityki } \\
\text { ryzyka }\end{array}$ & Liczba naruszeń & $\begin{array}{l}\text { Rozszerzenie audytu wewnętrznego; } \\
\text { modernizacja przestarzałej i niekom- } \\
\text { pletnej technologii }\end{array}$ \\
\hline $\begin{array}{l}\text { Utrzymywanie ryzyka rynkowego } \\
\text { w zakresie dopuszczalnych odchyleń }\end{array}$ & Ryzyko kredytowe & $\begin{array}{l}\text { Stosowanie metody VaR* w analizach } \\
\text { dotyczących wszystkich wdrażanych } \\
\text { w banku projektach z jednoczesnym } \\
\text { utworzeniem zespołu kontroli ryzyka; } \\
\text { Wycofywanie się z działań i projek- } \\
\text { tów o podwyższonym ryzyku }\end{array}$ \\
\hline $\begin{array}{l}\text { Doskonalenie modeli prognostycz- } \\
\text { nych w celu zwiększenia wrażliwości } \\
\text { tzw. stres testów }\end{array}$ & Dokładność prognozy & $\begin{array}{l}\text { Dostosowanie istniejących modeli } \\
\text { prognostycznych do nowych założeń }\end{array}$ \\
\hline $\begin{array}{l}\text { Ograniczenie ryzyka rynkowego w } \\
\text { sytuacjach krytycznych }\end{array}$ & $\begin{array}{l}\text { Wymogi kapitałowe } \\
\text { na zabezpieczanie } \\
\text { niezidentyfikowanych } \\
\text { strat }\end{array}$ & $\begin{array}{l}\text { Przegląd zasad i limitów oraz dostoso- } \\
\text { wanie regulacji i procedur }\end{array}$ \\
\hline
\end{tabular}

${ }^{*}$ Value at Risk.

Źródło: [https://www.db.com/company/en/our-strategy.htm].

Osiąganie celów perspektywy ryzyka powinno mieć bezpośredni wpływ na mierniki perspektywy finansowej. Na przykład większe ryzyko powinno być rekompensowane przez zwiększanie standardowego zwrotu w typowych warunkach. W związku z tym w perspektywie ryzyka pojawia się pytanie, które rodzaje ryzyka należy kontrolować, aby można było uzyskać długoterminowy i skorygowany o ryzyko zwrot. Umiejscowienie perspektywy ryzyka na mapie strategii powinno być między perspektywą finansową i klienta.

\section{Zakończenie}

Wdrożenie zrównoważonej karty wyników w bankach przynosi wiele korzyści. Po pierwsze: zmusza je do skupiania się nie tylko na miernikach finansowych, lecz również na miernikach niefinansowych, które w efekcie decydują o sukcesie finansowym tych organizacji. Po drugie: możliwość dostosowania struktury zrównoważonej karty wyników do aktualnych potrzeb banków poprzez dodanie piątej perspektywy - perspektywy ryzyka, zapewnia jeszcze lepsze zarządzanie tymi jednostkami. Nie oznacza to, że przed wyodrębnieniem tej piątej perspektywy zagadnienia dotyczące zarządzania w warunkach ryzyka były pomijane. Jednakże dopiero uświadomienie sobie, jak bardzo ważny, z punktu widzenia funkcjonowania banku, jest obszar zarządzania ryzykiem, spowodowało konieczność wyodrębnia tego obszaru i stworzenie, obok czterech klasycznych perspektyw, dodatkowej perspektywy: ryzyka. 


\section{Literatura}

Czerwińska T., Jajuga K. (red.), 2016, Ryzyko instytucji finansowych: wspótczesne trendy $i$ wyzwania, Wydawnictwo C.H. Beck, Warszawa.

Friedag H.R., Schmidt W., 2004, My Balanced Scorecard, Wydawnictwo C.H. Beck, Warszawa.

Iwanowicz-Drozdowska M., Jaworski W.L., Zawadzka Z., 2010, Bankowość. Zagadnienia podstawowe, Poltext, Warszawa.

Jajuga K. (red.), 2015, Zarzadzanie ryzykiem, Wydawnictwo Naukowe PWN, Warszawa.

Kaplan R.S., Norton D.P., 1992, The Balanced Scorecard - Measures That Drive Performance, Harvard Business Review, January-February.

Kaplan R.S., Norton D.P., 1996, Using the Balanced Scorecard as a Strategic Management System, Harvard Business Review, January-February.

Kaplan R.S., Norton D.P., 2001, Strategiczna Karta Wyników. Praktyka, CIM, Warszawa.

Kaplan R.S., Norton D.P., 2004, Strategy Map: Converting intangible assets into tangible outcomes, Harvard Business School Press, Boston.

Kaplan R.S., Norton D.P., 2011, Strategiczna Karta Wyników. Jak przełożyć strategię na dziatanie, Wydawnictwo Naukowe PWN, Warszawa.

Nieplowicz M., 2003, Zastosowane Strategicznej Karty Wyników w banku, Prace Naukowe Akademii Ekonomicznej im. Oskara Langego we Wrocławiu, nr 972.

Ustawa z dnia 29 sierpnia 1997 r. - Prawo bankowe, Dz.U. 1997 nr 140 poz. 939 z późn. zm.

\section{Źródło internetowe}

https://www.db.com/company/en/our-strategy.htm. 